\title{
Characterization of the altered form of the c-src gene product in neuronal cells
}

\author{
Joan Brugge, ${ }^{1}$ Patricia Cotton, ${ }^{1}$ Ana Lustig, ${ }^{1}$ Wes Yonemoto, ${ }^{1,3}$ Leah Lipsich, ${ }^{1,4}$ Paul Coussens, ${ }^{1,5}$ \\ John N. Barrett, ${ }^{2}$ Doris Nonner, ${ }^{2}$ and Robert W. Keane ${ }^{2}$ \\ ${ }^{1}$ Department of Microbiology, State University of New York, Stony Brook, New York 11794-8621 USA; ${ }^{2}$ Department of \\ Physiology and Biophysics, University of Miami School of Medicine, Miami, Florida 33101 USA
}

\begin{abstract}
The $\mathrm{pp60}^{\text {c-src }}$ protein that is expressed at high levels in cultures of neurons from rat embryos displays an altered mobility on SDS-polyacrylamide gels due to a structural difference in the amino-terminal region of the molecule. In this report we show that the expression of this unique form of $\mathrm{pp60}^{\text {c-src }}$, designated $\mathrm{pp60} \mathrm{0}^{\mathrm{c}-\mathrm{src}+1}$, is not restricted to cultured neuronal cells since the pp60 ${ }^{\mathrm{c}-\mathrm{src}}$ molecules expressed in tissues from avian and rat neural tissues also display a retarded electrophoretic mobility. The amino-terminal region from $\mathrm{pp}^{60^{--s r c t+1}}$ was found to contain a novel phosphorylated tryptic peptide that contains phosphoserine. However, this phosphorylation does not appear to be responsible for the retarded electrophoretic mobility of pp60 ${ }^{\mathrm{c}-\mathrm{src}+\mathrm{l}}$, since the mobility of this protein is not altered by phosphatase treatment under conditions that remove greater than $95 \%$ of the radiolabeled phosphate on $\mathrm{pp60}^{\text {-srscl+1. }}$. The altered electrophoretic form of $\mathrm{pp60}^{\text {c-src }}$ was also shown to be radiolabeled with $\left[{ }^{3} \mathrm{H}\right]$ myristate, indicating that $\mathrm{pp} 60^{\mathrm{c}-s r c}$ is fatty-acylated in neurons, as is pp60 ${ }^{\mathrm{c}-\mathrm{src}}$ in fibroblasts. The $\mathrm{pp} 60^{\mathrm{c}-\mathrm{src}}$ molecules synthesized in vitro using rabbit reticulocyte lysates programmed with mRNA from embryonic brain migrated more slowly on SDS-polyacrylamide gels than the pp60-src protein that was translated in vitro using RNA from embryonic limb tissue. These results suggest the possibility that the c-src mRNA expressed in neurons may undergo a unique form of processing to generate the structurally distinct form of neuronal $\mathbf{p p} 60^{\text {c-srcl+1 }}$.
\end{abstract}

[Key Words: pp60 ${ }^{\mathrm{c}-s \mathrm{rc}}$; c-src gene; tyrosine protein kinase; phosphorylation; neurons; RNA processing]

Received January 26, 1987; revised version received and accepted March 5, 1987.

The v-src gene that is responsible for oncogenic transformation by Rous sarcoma virus (RSV) has been shown to be a mutated homolog of a normal avian cellular gene, denoted c-src (Stehelin et al. 1976; Takeya and Hanafusa 1983; Bishop et al. 1985). The c-src gene is a highly conserved cellular gene that has been detected in humans (Anderson et al. 1985; Parker et al. 1985), as well as in lower eukaryotic species, including Drosophila (Hoffman et al. 1983; Simon et al. 1985) and Spongilla (Barnekow et al. 1984). The primary amino acid sequences of the avian c-src gene product, $\mathrm{pp} 60^{\mathrm{c}-\mathrm{src}}$, and the $\mathrm{v}-s r c$ gene product encoded by the Schmidt-Ruppin strain of RSV, pp60 ${ }^{\mathrm{v}-s r c}$, are identical, with the exception of a substitution of 12 amino acids at the carboxyl terminus, and 10 single amino differences scattered throughout the protein (Takeya and Hanafusa 1983; Levy et al. 1986). These mutations in the v-src gene have altered the functional behavior of the $s r c$ gene product. While both the cellular and viral src gene products ex-

3Present address: Department of Chemistry, University of California at San Diego, La Jolla, California 92093 USA.

${ }^{4}$ Present address: Genetic Systems, 3005 First Avenue, Seattle, Washington 98121 USA.

5resent address: Department of Microbiology and Public Health, Giltner Hall, Michigan State University, East Lansing, Michigan 48824 USA. pressed in fibroblasts contain tyrosine-specific protein kinase activity (Collett et al. 1979b; Oppermann et al. 1979; Rohrschneider et al. 1979), the specific activity of the fibroblastic pp60 c-src is about 20- to 100 -fold lower than that of pp60v-src (Coussens et al. 1985; Iba et al. 1985). In addition, the expression of pp60 ${ }^{\mathrm{c}-s r c}$ at levels comparable to the levels of pp60 ${ }^{\mathrm{v}-\mathrm{src}}$ found in RSV-transformed cells does not induce the multiple pleiotropic alterations in cellular growth and metabolism associated with oncogenic transformation (Iba et al. 1984; Parker et al. 1984; Shalloway et al. 1984). Current evidence suggests that most of the phenotypic changes induced in cells by pp $60^{\mathrm{v}-s r c}$ represent the activity of an unregulated, activated form of the src gene product, and that these events are not induced in normal cells by the activity of pp60 6 -src.

The functional role of $\mathrm{pp} 60^{\mathrm{c}-\mathrm{src}}$ in normal cells is not known. We, and others, have examined the expression of pp60 ${ }^{\mathrm{c}-\mathrm{src}}$ in tissues from developing chicken embryos to determine whether its pattern of expression would provide a clue to the function of this protein. Neural tissues, such as the brain, neural retina, and dorsal root ganglion, were found to contain 8- to 10 -fold greater levels of the c-src gene product and pp $60^{\mathrm{c}-\mathrm{src}}$-specific protein kinase activity compared with the levels observed in limb and other nonneural tissues or in chicken em- 
bryo fibroblasts (Cotton and Brugge 1983; Levy et al. 1984; Schartl and Barnekow 1984). The highest levels of activity were observed in embryonic neural tissues and were correlated with the differentiation of neurons and their withdrawal from the cell cycle. These results suggested that the expression of $\mathrm{pp} 6 \mathrm{O}^{\mathrm{c}-\mathrm{src}}$ is not restricted to proliferating cells. Consistent with this conclusion is the observation of Sorge and co-workers (Sorge et al. 1984) that immunohistochemical detection of $\mathrm{pp} 60^{\mathrm{c}-s \mathrm{rc}}$ is specifically associated with the postmitotic neuronal layer of embryonic neural retina. In addition, we have found recently that pure cultures of postmitotic, differentiated rat neurons possess 15- to 20-fold higher levels of pp60 $0^{\text {c-src }}$ than do cultured fibroblasts (Brugge et al. 1985). These results indicated that pp60-src may serve a function in differentiated neurons, or in the pathway involved in neuronal differentiation.

The pp $60^{\mathrm{c}-s r c}$ protein expressed in the cultures of pure neuronal cells from rat embryos displayed an altered electrophoretic mobility on SDS-polyacrylamide gels, indicating that the $\mathrm{pp} 60^{\mathrm{c}-\mathrm{src}}$ protein expressed in neurons is qualitatively different from the protein expressed in other cell types (Brugge et al. 1985). The alteration responsible for the retarded electrophoretic mobility of the neuronal form of $\mathrm{pp} 60^{\mathrm{c}-s r c}$ was localized to the aminoterminal 16,000 daltons of pp60-src (Brugge et al. 1985). The specific activity of this altered form of $\mathrm{pp} 60^{\mathrm{c}-s r c}$ was higher than that of pp60 6 -src expressed in astrocytes and in fibroblasts, as assayed by an immune-complex protein kinase assay using enolase as an exogenous substrate. These results suggest that the expression of the c-src gene is subject to cell-type specific modifications that alter the amino-terminal region of $\mathrm{pp} 60^{\mathrm{c}-s r c}$ and may influence its functional activity.

In this report, we examine further the pp60 $60^{\text {c-src }}$ protein expressed in neuronal cultures, as well as in neural tissues from chicken and rat embryos, to determine the nature of the alteration that is responsible for the retardation in electrophoretic mobility of this form of pp $60^{\mathrm{c}-s r c}$. Although the neuronal $\mathrm{pp} 60^{\mathrm{c}-s \mathrm{rc}}$ protein was shown to contain a novel site of serine phosphorylation, the results presented here suggest that the alteration in electrophoretic mobility is not due to a post-translational alteration of $\mathrm{pp} 60^{\mathrm{c}-s \mathrm{~s} c}$, but to an alteration in the processing of the c-src mRNA expressed in neurons.

\section{Results}

\section{Analysis of pp $60^{c \text {-src }}$ expressed in neural tissues}

A comparison of the electrophoretic mobilities of pp $60^{\text {c-ssc }}$ molecules immunoprecipitated from lysates of [32 P]orthophosphate-labeled brain, limb, and neural retina obtained from 10-day-old chicken embryos indicated that the pp60 ${ }^{\mathrm{c}-s r c}$ protein from brain and neural retina migrated with a slightly slower electrophoretic mobility than that of pp60-src from limb. To map the position of the alteration responsible for the difference in the mobility of $\mathrm{pp} 60^{\mathrm{c}-s r c}$ from these tissues, the c-src gene products were excised and mapped by partial proteolysis using Staphylococcus aureus V8 protease (Fig. 1B).
A diagram showing the V8 protease cleavage sites is shown in Figure 1A. The mobility of the V2 peptide, derived from the carboxyl 26,000 daltons of pp60-ssc $/$ Collett et al. 1979a), was invariant in the pp60 c-src molecules from all tissues. The Vl peptide [which represents the
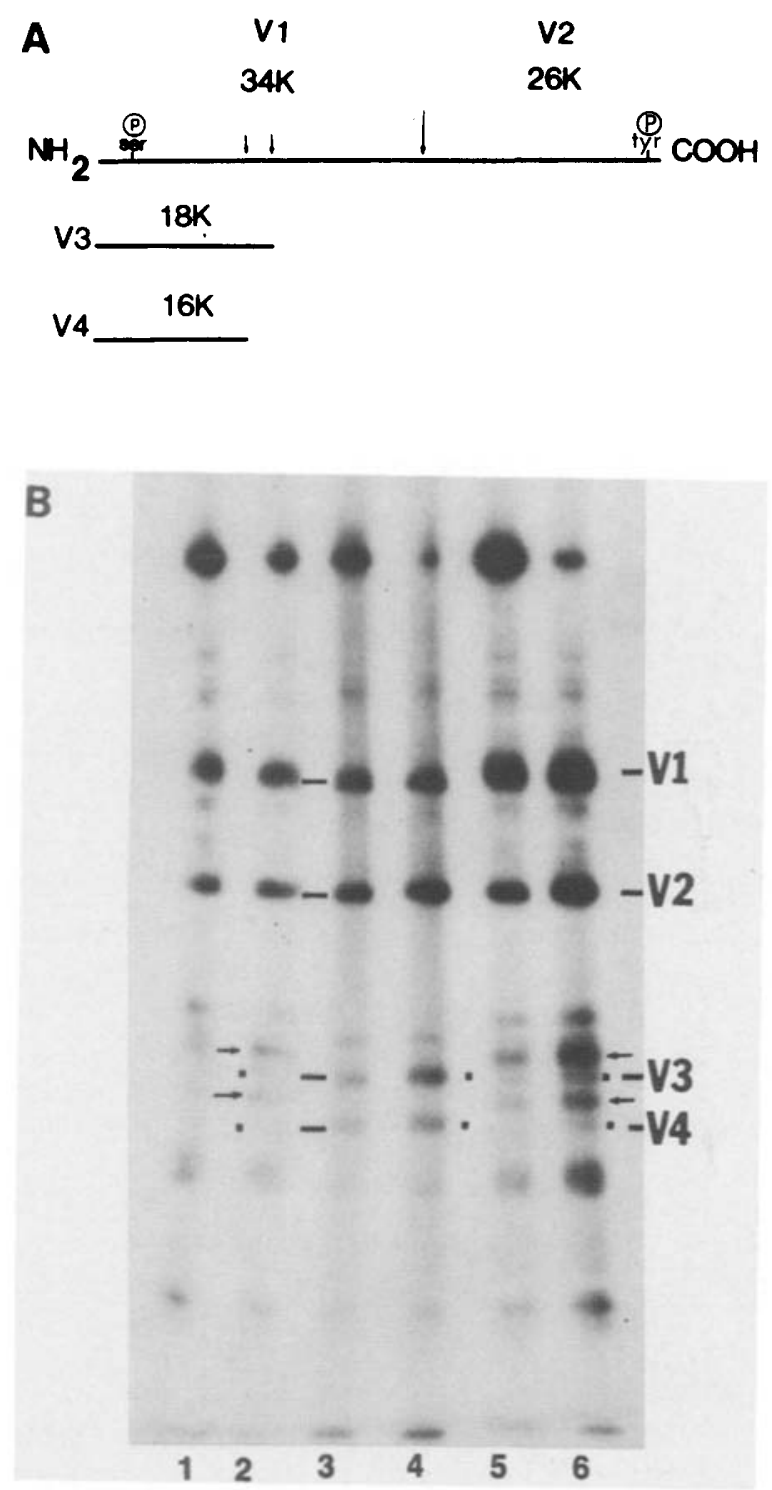

Figure 1. Partial peptide analysis of pp60 c-src from different tissues. $(A)$ Map of pp60 $60^{c-s r c}$ showing the cleavage pattern resulting from treatment with $S$. aureus V-8 protease (Collett et al. 1979a). (B) Brain (lanes 1 and 2), limb (lanes 3 and 4), and neural retina (lanes 5 and 6) tissues were removed from a 10day-old chicken embryo, labeled with $2 \mathrm{mCi} / \mathrm{ml}$ of ${ }^{32} \mathrm{P}_{\mathrm{i}}$ for $4 \mathrm{hr}$, lysed in $1 \mathrm{ml}$ of SLB and immunoprecipitated with $10 \mu \mathrm{l}$ of TBR serum. The samples were electrophoresed on a $10 \%$ polyacrylamide gel and the dried gel was exposed for $15 \mathrm{hr}$ on XAR film using a Lightning-Plus screen. The pp $60^{\mathrm{c}-s r c}$ protein bands were excised and were mapped by partial proteolytic cleavage using $S$. aureus V-8 protein as described in Materials and methods. (Lanes 1, 3, and 5) $10 \mathrm{ng}$ of V-8 protease; (lanes 2, 4, and 6) $50 \mathrm{ng}$ of $\mathrm{V}-8$ protease. The arrows designate the position of the altered electrophoretic forms of V3 and V4 detected in neural tissues. 


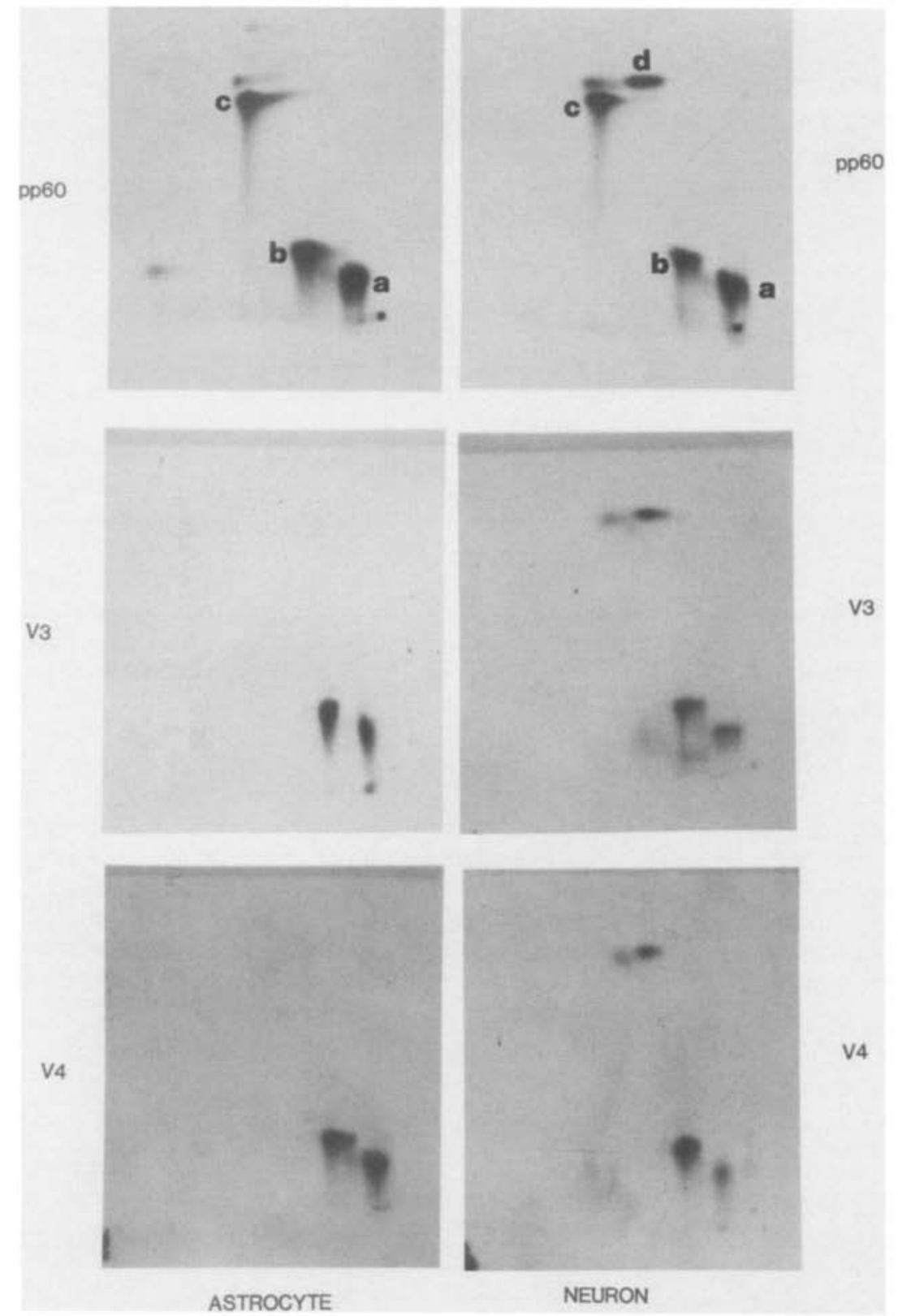

Figure 2. Analysis of the phosphorylated peptides derived from trypsin cleavage of the neuronal and astrocytic forms of pp60 ${ }^{\mathrm{c}-s r c}$. Pure cultures of rat neuronal and astrocytic cells (Brugge et al. 1985) were labeled with ${ }^{32} \mathrm{P}_{\mathrm{i}}$ for $16 \mathrm{hr}$. pp $60^{\mathrm{c}-s r c}$ was immunoprecipitated with MAb 327 and electrophoresed on a $7.5 \%$ SDS-polyacrylamide gel as described in Materials and methods. The pp60 $60^{\mathrm{c}-s \mathrm{rc}}$ bands were excised and one-half of each band was electrophoresed in the presence of $200 \mathrm{ng}$ of V-8 protease to generate V2, V3, and V4 peptides. The intact $60-\mathrm{kD}$ band and the V3 and V4 peptides were eluted from the gels and subjected to trypsin cleavage as described in Materials and methods. (The peptides derived from V2 are not shown here. See Fig. 3 for neuronal V2.) Electrophoresis was from right to left; chromatography, from bottom to top. amino 34,000 daltons of pp60 c-src (Collett et al. 1979a)] from the brain and neural retinal pp $60^{\mathrm{c}-\mathrm{s} r c}$ displayed a slightly slower mobility than the V1 peptide derived from the limb pp60 ${ }^{c-s r c}$; yet, more distinct differences in the mobilities of the secondary V1 cleavage products, V3 and V4, were observed. Although the peptide map of pp $60^{c-s r c}$ from brain and neural retina contained faint bands that comigrated with the V3 and V4 peptides from limb pp60 ${ }^{\mathrm{c}-s \mathrm{rc}}$, the major ${ }^{32} \mathrm{P}$-labeled peptides that $\mathrm{mi}-$ grated in this region displayed a retarded electrophoretic mobility (compared to the limb pp60-src V3 and V4 peptides). The neural retina and brain pp $60^{\text {c-src }}$ peptide maps also contained a novel ${ }^{32} \mathrm{P}$-labeled peptide of $M_{\mathrm{r}} 13,000$. The V8-cleavage profile of $\mathrm{pp} 60^{\mathrm{c}-\mathrm{s} r c}$ from the radiolabeled brain and neural retina was similar to that of pp60 c-src derived from pure cultures of neuronal cells from embryonic rat brain (Brugge et al. 1985), indicating that the previously described alteration in the structure of pp $60^{\mathrm{c}-s r c}$ is not restricted to cultured neurons. In addition, these results indicate that the neuron-specific form of $\mathrm{pp} 60^{\mathrm{c}-s r c}$, which will be designated $\mathrm{pp} 60^{\mathrm{c}-s r c \mid+1}$, represents the majority of the total population of c-src gene products that are radiolabeled in brain tissues from 10day embryos.

Samples of brain, neural retina, and limb were removed from chicken embryos at various stages of development to examine the expression of the neural-specific form of pp60 $6 \mathrm{c}^{\mathrm{csrc}}$ (data not shown). Prior to day $5 \mathrm{of} \mathrm{em}$ bryonic development, only the unaltered V3 and V4 peptides were observed in maps of pp60 $0^{\text {cssc }}$ from all tissues examined. After day 5, the retarded electrophoretic forms of V3 and V4 were detected in pp60 $0^{\mathrm{c}-s r c}$ derived from brain tissues and after day 6 , these forms were detected in neural retinal pp $60^{c-s r c}$ samples. These unique 
V3 and V4 peptides were not observed in any other tissues examined including heart, kidney, liver, lung, dermis, or testis. Tissues from rat and mouse brain also contained pp $60^{\mathrm{c}-s \mathrm{rcl}+1}$, indicating that the modification is present in the neural tissues of mammals as well as in avian species.

\section{Analysis of the phosphorylation of $p p 60^{c \text {-src }}$ from} neurons and astrocytes

Since the shift in mobility of pp $60^{\mathrm{c}-s r c}$ in neurons could be due to an alteration in the phosphorylation of this protein, we analyzed the phosphopeptides derived from pp60 ${ }^{\mathrm{c}-s r c}$ from cultures of neurons and astrocytes (Fig. 2). The two-dimensional peptide maps of pp60 6 -src from both cell types are similar, except that the neuronal pp60 $60^{\text {csrcl+1 }}$ protein contains an additional phosphorylated peptide (denoted d) which is not detected in astrocytic pp $60^{\mathrm{c}-s r c}$. The a and b peptides contain phosphoserine (data not shown) and represent the major phosphopeptides derived from the amino-terminal V3 and V4 fragments. These peptides are believed to contain the serine-17 phosphorylation site. Peptide c contains phosphotyrosine (data not shown) and is the only peptide derived from the $\mathrm{V} 8$ protease-generated carboxy-terminalV2 peptide (see Fig. 3, below). This peptide is believed to contain the tyrosine -527 site of phosphorylation (Cooper et al. 1986). The novel neuron-specific peptide d is contained within the amino-terminal V3 and V4 peptides derived from V8 protease cleavage and has been found to contain phosphoserine (data not shown). Figure 3 shows a one-dimensional separation of the tryptic phosphopeptides eluted from the two-dimensional maps of neuronal pp $60^{\mathrm{c}-s \mathrm{rcl}+1}$ in Figure 2, as well as total tryptic peptides derived from intact $\mathrm{pp} 60^{\mathrm{c}-\mathrm{src}}$ and the V8-protease-derived $\mathrm{V} 2$ and V3 peptides. All of the major sites of phosphorylation are resolved on these $27 \%$ Tris-borate gels, which provide a preliminary indication of the approximate molecular weight of the peptides, and allow more reproducible solubilization of each peptide. This latter factor is important in determining the stoichiometry of phosphorylation at each site. Comparison of the total tryptic peptides derived from neuronal and astrocytic pp60-src revealed a neuron-specific peptide of $M_{\mathrm{r}} 2800$. This peptide comigrated with the $\mathrm{d}$ peptide obtained from the two-dimensional map of neuronal pp $60^{\mathrm{c}-s r c}$ shown in Figure 2, and the neuron-specific peptide derived from the V3 fragment from V8-proteolysis (lane 7). This provides further confirmation of the neuronal specificity of this peptide derived from the amino-terminal region of pp $60^{\mathrm{c}-s \mathrm{rcl}+1}$. The ratio of ${ }^{32} \mathrm{P}$ incorporation of peptide $\mathrm{d}$ to the combined incorporation of the other peptides from the V3 fragment (peptides a and b) was approximately $1: 5$. If phosphorylation of peptide $\mathrm{d}$ was responsible for the shift in electrophoretic mobility of the neuronal pp $60^{\text {c-srcl+1 }}$ protein, a ratio of at least $0.9: 1$ would be expected, since $90 \%$ of the pp $60^{\mathrm{c}-s \mathrm{c}}$ molecules expressed in neuronal cells display a retarded electrophoretic mobility.

The mobility of peptide $\mathrm{c}$ is consistent with its having the predicted molecular weight of the tyrosine-527-containing tryptic peptide. In addition, peptide c comigrates with the tryptic peptide derived from the V8 proteasederived V2 fragment (lanes 9 and 10). The mobilities of peptides $\mathrm{a}$ and $\mathrm{b}$ are not consistent with the predicted

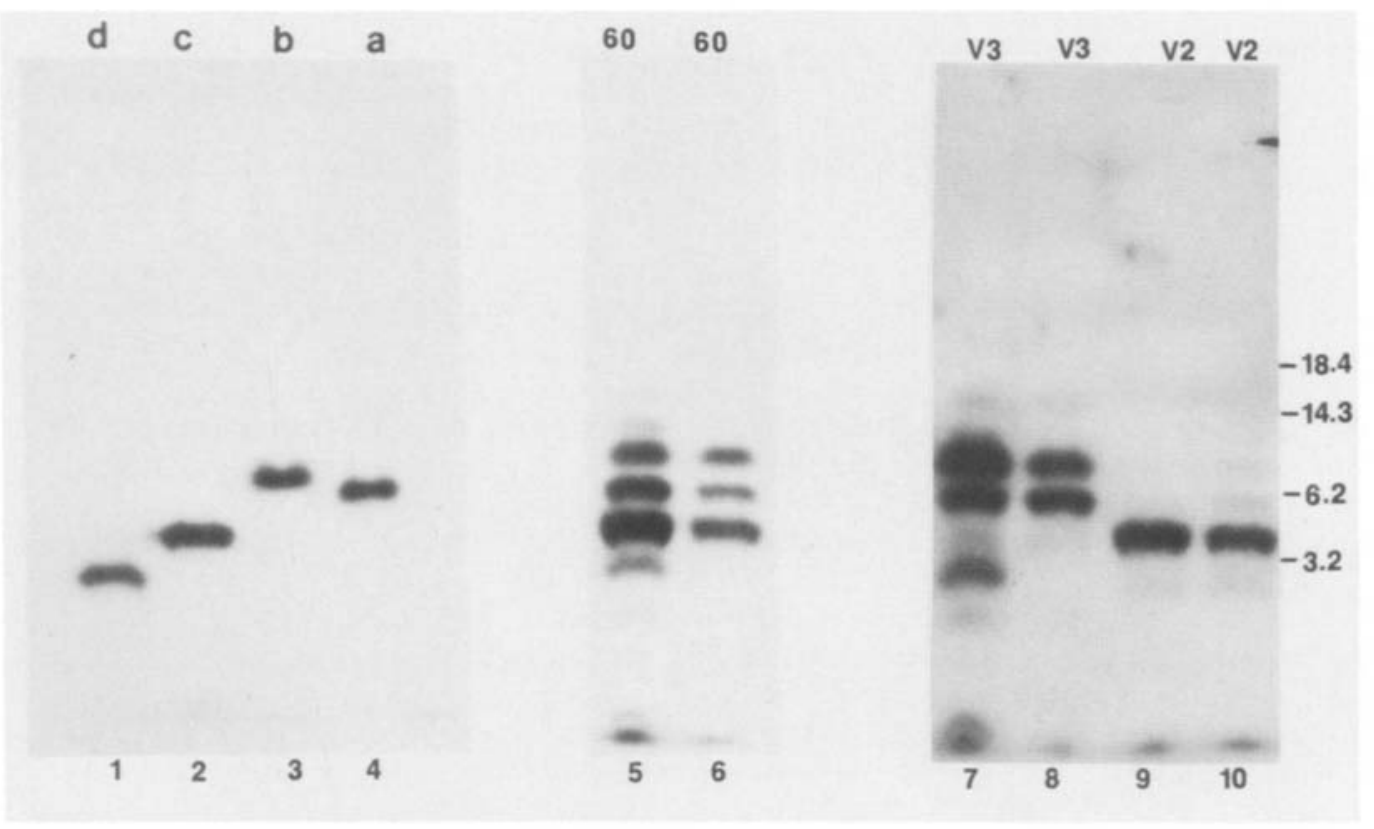

Figure 3. Separation of the tryptic phosphopeptides on one-dimensional Tris-borate gels. (Lanes 1-4) Tryptic phosphopeptides eluted from two-dimensional maps shown in Fig. 2 (upper right panel). (Lane 1) d peptide; (lane 2) c peptide; (lane 3) b peptide; (lane 4) a peptide; (lanes 5 and 6) total tryptic digestion products of pp60 ${ }^{\text {-src }}$ from neuronal (lane 5) and astrocytic (lane 6) cultures labeled with ${ }^{32} \mathrm{P}$ as described in Fig. 2; (lanes 7 and 9 ) tryptic phosphopeptides from the V8 protease-derived V3, and V2, respectively, of rat neuronal pp60 ${ }^{\mathrm{c}-s \mathrm{sc}}$; (lanes 8 and 10) tryptic phosphopeptides derived from the V8 protease-derived V3 and V2 fragments, respectively, of rat astrocytic pp $60^{\mathrm{c}-s r c}$. 
mobility $\left(M_{\mathrm{r}} 2600\right)$ of the avian serine-17-containing peptide; however, it is difficult to predict the size of the serine-17-containing peptide from rat cells since the rat c-src gene has not been sequenced.

We have observed a tryptic phosphopeptide with a mobility similar to peptide $d$ in pp $60^{\text {c-src }}$ derived from brain and other neural tissues excised from 10-day chicken embryos (data not shown), indicating that this novel site of phosphorylation has been conserved in rats and chickens.

\section{Analysis of the electrophoretic mobility of neuronal pp $60^{c \text {-ssc }}$ following phosphatase treatment}

To examine whether removal of phosphate residues from $\mathrm{pp} 60^{\mathrm{c}-\mathrm{srcl}+1}$ altered the electrophoretic mobility of this protein, $\left[{ }^{35} S\right]$ methionine-labeled $\mathrm{pp} 60^{\mathrm{c}-\mathrm{s} r c}$ from rat neuronal cultures was treated with potato acid phosphatase in vitro under conditions that reduced the level of ${ }^{32}$ P-labeled pp60 ${ }^{\text {c-srcl+) }} 90-95 \%$ (see controls, Fig. 4,

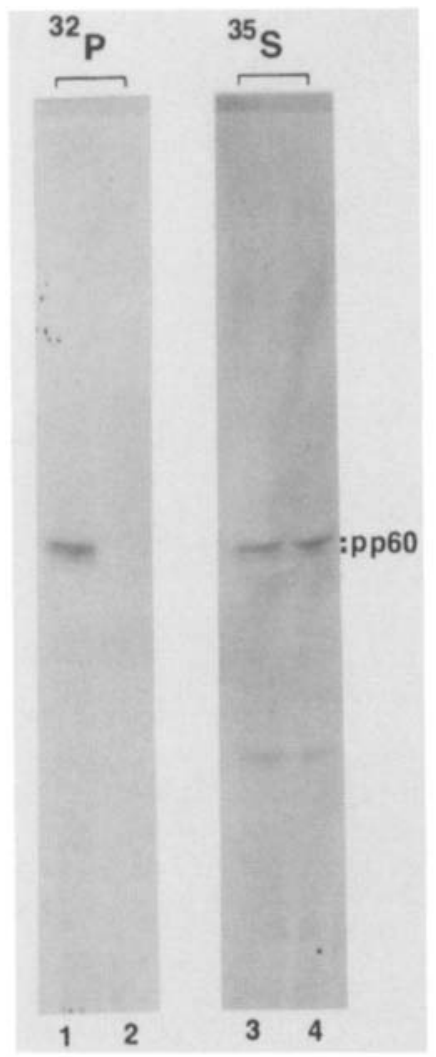

Figure 4. Analysis of the electrophoretic mobility of neuronal pp $60^{\text {c-src }}$ following phosphatase treatment. Pure cultures of rat neuronal cells were labeled with ${ }^{32} \mathrm{P}(1 \mathrm{mCi} / \mathrm{ml})$ or $\left[{ }^{35} \mathrm{~S}\right]$ methionine $(100 \mu \mathrm{Ci} / \mathrm{ml})$ for $4 \mathrm{hr}$ in DME minus phosphate or methionine. pp60 $60^{\mathrm{c}-s r c}$ was then immunoprecipitated with MAb 327. Following the washes of the immunoprecipitates with RIPA buffer, the immune-complexes were washed one time with PA buffer. One sample was incubated in this buffer for $10 \mathrm{~min}$ (lanes 1 and 3); the other sample was incubated for the same period in this buffer plus $6 \mu \mathrm{g}$ of potato acid phosphatase (lanes 2 and 4), as described by Cooper and King (1986). The samples were then subject to electrophoresis on $7.5 \%$ SDS-polyacrylamide gels. The small squares indicate the positions of the two forms of $\mathrm{pp} 60^{\mathrm{c}-s r c}$ in neurons. lanes 1 and 2). This treatment did not alter the ratio of the upper and lower forms of pp60 c-src in neurons. These results indicate that phosphorylation of peptide $d$ is not responsible for the shift in electrophoretic mobility of the pp60 ${ }^{\mathrm{c}-s \mathrm{~s} c}$ protein expressed in neurons.

\section{Analysis of the myristylation of the neuronal pp $60^{c-s r c}$ protein}

Both the viral and cellular forms of pp60 $0^{\mathrm{c}-s r c}$ expressed in fibroblasts contain covalently bound myristic acid (Buss et al. 1984; Schultz et al. 1985). This modification appears to take place either during translation or immediately following translation of $\mathrm{pp} 60^{\mathrm{c}-\mathrm{s} r c}$. Since the addition of this fatty acid might be expected to affect the electrophoretic mobility of $\mathrm{pp} 60^{\mathrm{c}-s r c}$, we labeled the neuronal and astrocytic cultures with $\left[{ }^{3} \mathrm{H}\right]$ myristic acid (Fig. $5)$ and analyzed the mobility of pp60 ${ }^{\text {cssc }}$ from these cultures. The pp $60^{\mathrm{c}-s \mathrm{rc}}$ protein extracted from $\left[{ }^{3} \mathrm{H}\right]$ myristatelabeled rat neurons displayed a retarded electrophoretic mobility compared to the $\left[{ }^{3} \mathrm{H}\right]$ myristate- and $\left[{ }^{35} \mathrm{~S}\right]$ methionine-labeled $\mathrm{pp} 60^{\mathrm{c}-\mathrm{src}}$ protein from astrocytes and fibroblasts. These results demonstrate that the altered form of pp $60^{\mathrm{c}-s r c}$ expressed in neurons is myristylated and, thus, rule out the possibility that the absence of myristylation is responsible for the retarded electrophoretic mobility of neuronal pp $60^{\mathrm{c}-s r c}$.

\section{Analysis of the neuronal pp $60^{c \text {-src }}$ protein synthesized during short pulses with radiolabeled methionine}

The cultures of neuronal cells were radiolabeled for either $10 \mathrm{~min}$ or $4 \mathrm{hr}$ with $\left[{ }^{35} \mathrm{~S}\right]$ methionine. The electrophoretic mobility of pp $60^{\text {c-src }}$ molecules immunoprecipitated from lysates of these cultures was compared to that of pp $60^{\mathrm{c}-s r c}$ extracted from astrocytic cells radiolabeled continuously for $4 \mathrm{hr}$ (Fig. 6). The ratio of [ $\left.{ }^{35} \mathrm{~S}\right] \mathrm{me}$ thionine incorporation in the lower and upper forms of pp60 ${ }^{c-s r c}$ was similar for pp $60^{c-s r c}$ extracted from neurons labeled for either $10 \mathrm{~min}$ or $4 \mathrm{hr}$. This result suggested that the modification responsible for the altered electrophoretic mobility of $\mathrm{pp} 60^{\mathrm{c}-s \mathrm{sc}}$ in neurons occurs either co-translationally or immediately following translation, or that there is an alteration in the mRNA encoding this protein that is responsible for the altered structure of this src gene product.

Analysis of the pp $60^{c-s r c}$ protein translated in cell-free in vitro translation reactions

All of the preceding experiments suggested that the altered form of $\mathrm{pp} 60^{\mathrm{c}-\mathrm{src}}$ expressed in neurons was not generated by a post-translational modification of pp $60^{\mathrm{c}-s r c}$. To examine the possibility that the neuronal c-src gene product was translated from a unique mRNA, poly(A)containing RNA was extracted from brain and limb tissues from 10-day chicken embryos and used to program the translation of pp $60^{c-s r c}$ in rabbit reticulocyte lysates (Fig. 7). As markers for the mobility of pp60 $60^{\mathrm{c}-s \mathrm{rc}}$, fibroblasts and dissociated brain cells were radiolabeled with $\left.{ }^{35} \mathrm{~S}\right]$ methionine in vivo. The pp60 ${ }^{\mathrm{c}-s r c}$ protein trans- 


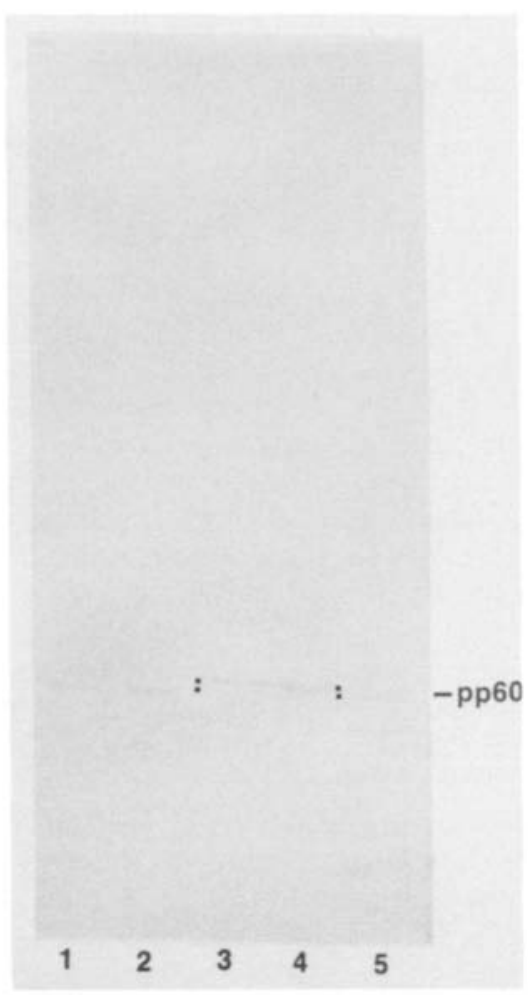

Figure 5. Analysis of $\mathrm{pp} 60^{\mathrm{c}-s \mathrm{~s} c}$ from fibroblasts, neurons, and astrocytes labeled with $\left[{ }^{35} \mathrm{~S}\right]$ methionine or $\left[{ }^{3} \mathrm{H}\right]$ myristic acids. Rat astrocytic cultures (lanes 1 and 2), rat neuronal cultures (lanes 3 and 4), and mouse NIH-(pMcsrc/cos/A cells expressing the chicken $\mathrm{pp} 60^{\mathrm{c}-s \mathrm{~s}}$ protein (lane 5) were radiolabeled with 100 $\mu \mathrm{Ci}$ of $\left[{ }^{35} \mathrm{~S}\right]$ methionine (lanes 2,4 , and 5 ) or $200 \mu \mathrm{Ci}$ of $\left[{ }^{3} \mathrm{H} \mid \mathrm{my}-\right.$ ristic acid (lanes 1 and 3) for $4 \mathrm{hr}$. pp60 $60^{\mathrm{c}-s r c}$ was immunoprecipitated from cell lysates with MAb 327 as described. The samples were electrophoresed on a $7.5 \%$ SDS-polyacrylamide gel. (Autoradiographic exposure, 30 days.) The small squares indicate the positions of the two electrophoretic forms of $\mathrm{pp} 60^{\mathrm{c}-s \mathrm{sc}}$.

lated in lysates programmed with chicken brain RNA migrated with a slower electrophoretic mobility than the pp $60^{\mathrm{c}-s i c}$ protein translated from limb RNA and the protein labeled in vivo in fibroblasts, and displayed an electrophoretic mobility similar to that of the upper

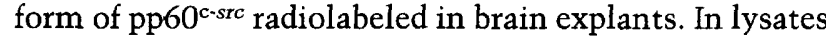
programmed with brain RNA, we were unable to detect an in vitro translation product that comigrated with the lower form of pp60. This result is consistent with the possibility that the majority of the c-src mRNA in brains from 10-day-old embryos encode the slower-migrating form of pp60 $60^{\mathrm{c}-s r c}$ and is consistent with the ratio of the upper to the lower form of $\mathrm{pp} 60^{\mathrm{c}-s \mathrm{~s} c}$ that was observed in the ${ }^{32} \mathrm{P}$-labeled brain cells shown in Figure 1. [The ${ }^{35} \mathrm{~S}$ marker shown in this figure was obtained from older embryos, where we typically observe a lower ratio of the upper to the lower form of pp60 c-src when the cells are labeled in culture. This reflects both a slight reduction in the proportion of the upper form of pp60, and a more significant reduction in the labeling efficiency of the cells that express this form of pp60 (since immunoblots indicate that the level of upper form is only slightly re- duced in the older embryonic brains).] The evidence that the upper form of $\mathrm{pp} 60^{\mathrm{c}-\mathrm{s} s c}$ is translated in vitro from brain RNA suggests the possibility that the mRNA that encodes this form of pp60 ${ }^{c-s r c}$ may undergo a unique pattern of processing in neurons that is responsible for the production of a structurally distinct form of $\mathrm{pp} 60^{\mathrm{c}-s \mathrm{~s} c}$.

\section{Discussion}

The expression of the c-src gene in cultured neuronal cells can be distinguished from that of the c-src gene in other cell types at several different levels. Quantitatively, there are 10- to 20-fold higher levels of the c-src gene product in primary cultures of neuronal cells than in cultured fibroblasts. There are also several qualitative differences between the $\mathrm{c}$-src gene product expressed in neuronal cells and other cell types: (1) The neuronal form of pp $60^{\mathrm{c}-s r c}$ displays slightly retarded electrophoretic mobility compared with other forms of $\mathrm{pp} 60^{\mathrm{c}-\mathrm{ssc}}$

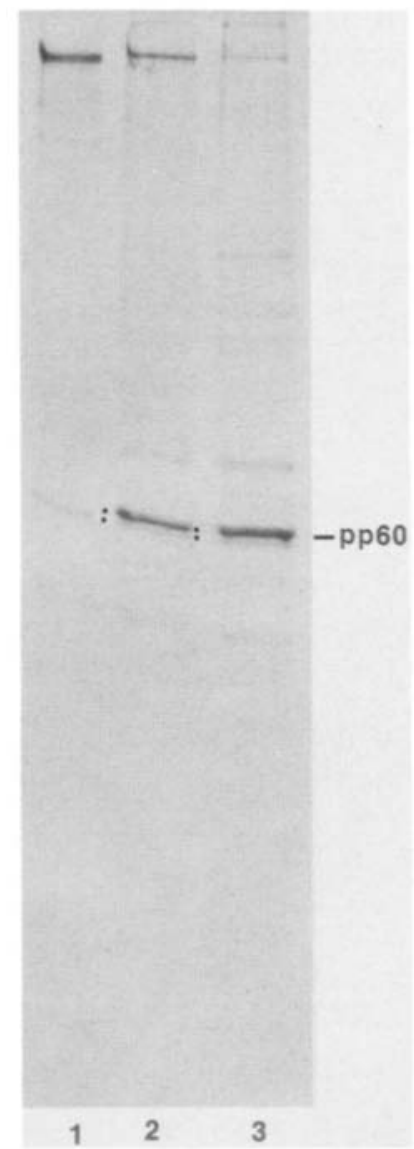

Figure 6. Analysis of pp60 6 -src protein radiolabeled with $\left[{ }^{35} \mathrm{~S}\right]$ methionine for $10 \mathrm{~min}$ or $4 \mathrm{hr}$. Pure cultures of rat neuronal (lanes 2 and 3) or astrocytic (lane 1) cells were incubated in DME minus methionine for $1 \mathrm{hr}$; the cells were then incubated in DME minus methionine supplemented with $500 \mu \mathrm{l} \mathrm{Ci} / \mathrm{ml}$ of $\left[{ }^{35} \mathrm{~S}\right]$ methionine for $10 \mathrm{~min}$ (lane 2) or $100 \mu \mathrm{Ci} / \mathrm{ml}$ of $\left.{ }^{35} \mathrm{~S}\right] \mathrm{methi}-$ onine for $4 \mathrm{hr}$ (lanes 1 and 3). pp60 ${ }^{\mathrm{c}-s r c}$ was immunoprecipitated from cell lysates as described in Materials and methods and the samples were electrophoresed on $7.5 \%$ SDS-polyacrylamide gels. 


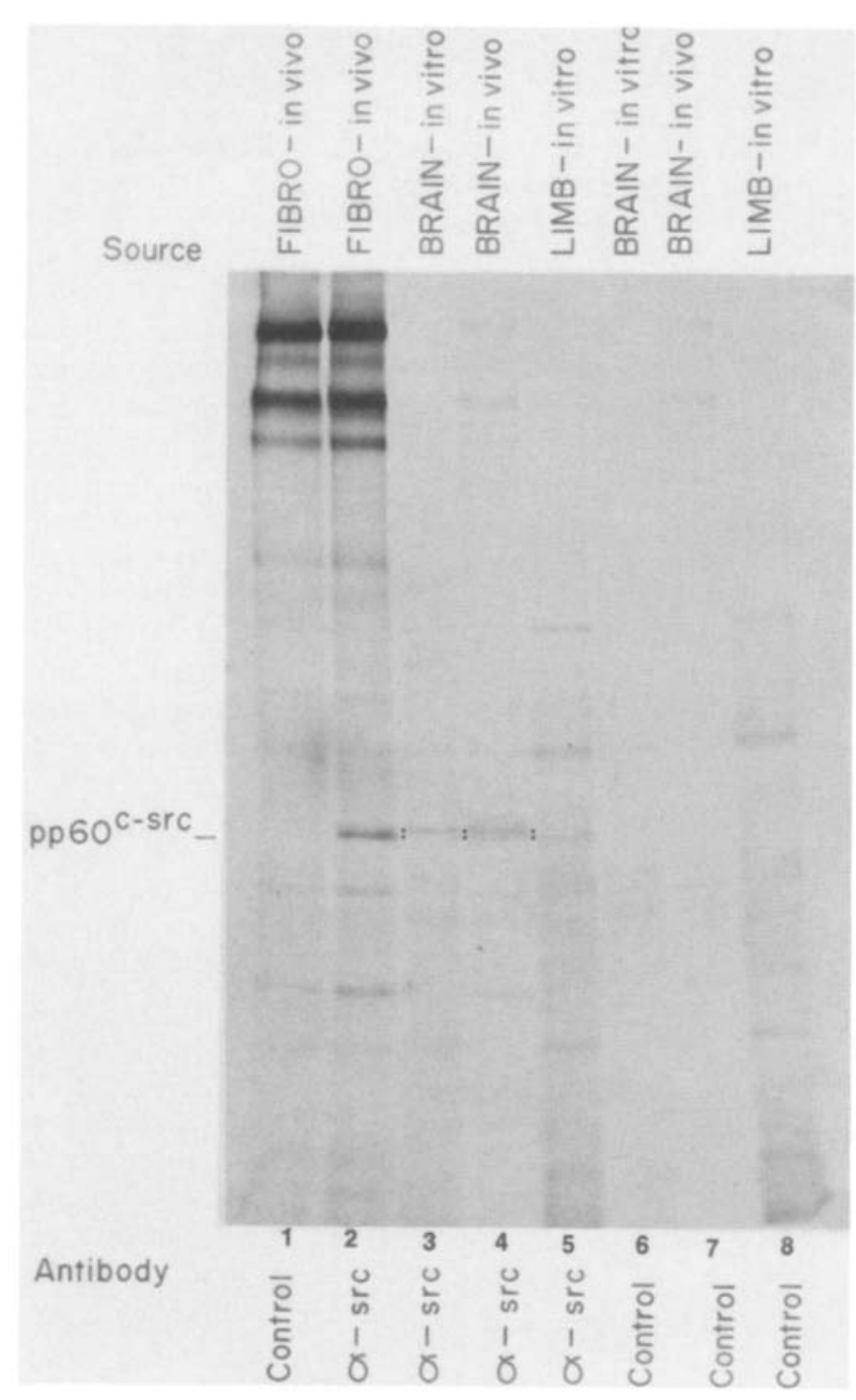

Figure 7. Analysis of the pp60 $60^{c-s r c}$ protein translated in vitro using rabbit reticulocyte lysates programmed with RNA extracted from embryonic limb and brain. Five micrograms of polyadenylated RNA from the brain (lanes 3 and 6) and limb (lanes 5 and 8) of 10-day-old chicken embryos was incubated with $500 \mu \mathrm{l}$ of rabbit reticulocyte cell lysate (ProMega Biotec) and $500 \mu \mathrm{Ci}$ of $\left.{ }^{35} \mathrm{~S}\right]$ methionine in 10 separate reactions. After $45 \mathrm{~min}$, the lysates were pooled and incubated with an equal volume of lysate from mouse NIH-(pMcsrc/cos)A cells to provide carrier pp $60^{\mathrm{c}-\mathrm{s} s c}$ protein for the immunoprecipitations. The lysates were then incubated with anti-mouse Ig (lanes 6 and 8 ) or MAb 327 (lanes 3 and 5) and processed as described in Materials and methods for immunoprecipitation assays. As markers for $\mathrm{pp} 60^{\mathrm{c}-s r c}$ electrophoretic mobility, the following samples were included: (lanes 1 and 2) immunoprecipitates from lysates of mouse $\mathrm{NIH}-(\mathrm{pMcsrc} / \mathrm{cos}) \mathrm{A}$ cells labeled with $100 \mu \mathrm{Ci}$ $\left.{ }^{35} \mathrm{~S}\right]$ methionine for $4 \mathrm{hr}$. (Lanes 4 and 7) Immunoprecipitates from lysates of brain tissue excised from a 14-day-old chicken embryo and labeled with $100 \mu \mathrm{Ci}$ of ${ }^{35}$ S/methionine for $4 \mathrm{hr}$. The lysates were incubated with either anti-mouse Ig (lanes 1 and 7), or MAb 327 (lanes 2 and 4). The samples were electrophoresed on $7.5 \%$ SDS-polyacrylamide gels. (Autoradiographic exposure, 60 days).
(Brugge et al. 1985). (2) The pp60 c-src protein expressed in neuronal cells contains a novel site of serine phosphorylation within the amino-terminal 16,000 daltons (this report). (3) The neuronal form of $\mathrm{pp} 60^{\mathrm{c}-s r c}$ displays a higher specific activity in immune complex kinase assays using enolase as exogenous substrate (Brugge et al. 1985).

The evidence presented in this report does not support the possibility that the altered electrophoretic form of pp60 $60^{\text {cssc }}$ expressed in neurons results from a post-translational modification of pp60-src. The earliest detectable form of $\mathrm{pp} 60^{\mathrm{c}-s \mathrm{sc}}$ observed in short-term pulses with $\left.{ }^{35} \mathrm{~S}\right]$ methionine migrates with a retarded mobility similar to the mature neuronal form of $\mathrm{pp} 60^{\mathrm{c}-s \mathrm{sc}}$. Although this form of the c-src gene product contains an additional site(s) of phosphorylation within the region of pp $60^{c-s r c}$ that contains the structural alteration, analysis of the stoichiometry of phosphorylation at this site, and the electrophoretic mobility of phosphatase-treated neuronal pp60 $60^{\mathrm{c}-s r c}$, indicate that this modification is not responsible for the alteration in mobility of neuronal pp $60^{\mathrm{c}-s r c}$. In addition, we have shown that the $\mathrm{pp} 60^{\mathrm{c}-s r c}$ protein expressed in neuronal cells is modified by the addition of myristic acid, similar to the pp $60^{\mathrm{c}-s \mathrm{rc}}$ protein expressed in fibroblasts.

Preliminary analysis of the mobility of the pp60-src protein translated in vitro in lysates programmed with brain RNA suggests that the altered form of $p p 60^{\mathrm{c}-s r c}$ is translated from a unique species of mRNA. It is unlikely that the altered mobility of the in vitro translation product from brain RNA results from a post-translational modification of $\mathrm{pp} 60^{\mathrm{c}-s r c}$ because the translation product from limb RNA is incubated in an identical reticulocyte lysate. An alternative explanation for these results is that the protein that is immunoprecipitated from neuronal cultures with the monoclonal antibody directed against pp60 is encoded by a gene closely related to, but distinct from, the c-src gene. Several lines of evidence argue against this possibility: (1) The monoclonal antibody 327 that immunoprecipitates the pp $60^{\text {c-srcl+1 }}$ does not cross-react with any of the other tyrosine kinases that have been examined (including pp90sag-yes, pp62 c-yes, pp68gag-ros, pp140v-gag-fps, pp160v-gag-abl, pp70v-gag-frg, and pp58 $8^{\text {lck }}$ (Lipsich et al. 1983; L. Lipsich and J. Brugge, unpubl.). (2) The a, b, and c phosphopeptides from the two-dimensional phosphopeptide maps of the pp60 $6{ }^{\mathrm{c}-s r c}$ from astrocytes and neurons display the same pattern of mobility, indicating that the amino acids within these peptides are similar, if not identical, in these two proteins. The two oncogenes that encode proteins which have electrophoretic mobilities similar to that of neuronal pp60 $0^{\mathrm{c}-s t c}$ are c-syn (61,000 daltons) (Semba et al. 1986) and c-yes $(62,000$ daltons) (Sukegawa et al. 1987). The predicted tryptic peptide that would contain the serine-17 phosphorylation site on these molecules is grossly different in size and charge from the analogous peptide $\mathrm{pp} 60^{\mathrm{c}-s r c}$. In addition, Sudol and Hanafusa (1986) have shown that monoclonal antibody 327 does not recognize pp62-yes. (3) The neuronal form of pp $60^{\mathrm{c}-s r c}$ is detected by all of the mono- 
clonal antibodies isolated in our laboratory that we have examined (P. Cotton and J. Brugge, unpubl.); at least six of these antibodies appear to recognize different epitopes of $\mathrm{pp} 60^{\mathrm{c}-\mathrm{s} r \mathrm{c}}$.

Thus, while we cannot totally exclude the possibility that the neuronal protein of $M_{\mathrm{r}} 61 \mathrm{~K}$ is not encoded by the c-src gene, it is more likely that this protein is translated from a uniquely processed form of c-src mRNA. The analysis of cDNAs encoding the $c-a b 1$ gene product provides a precedent for this possibility. Four alternate $5^{\prime}$ exons for c- $a b l$ mRNA molecules were identified (Ben-Neriah et al. 1986); each 5' exon encodes a unique set of amino-terminal sequences of the c-abl gene product. The c- $a b 1$ gene product is similar to $\mathrm{pp} 60^{\mathrm{c}-\mathrm{src}}$ in that it does not span the plasma membrane, and at least a portion of pp145 ${ }^{\mathrm{c}-a b l}$ is localized on the cytoplasmic face of the plasma membrane. Ben-Neriah and coworkers have postulated that the alternate amino-terminal regions of the c- $a b l$ gene products confer specificity to the interactions of the c-abl protein with other membrane proteins that might regulate the activity of this protein, possibly transmembrane receptor proteins (Ben-Neriah et al. 1986). In the case of pp60 $0^{\text {c-src }}$, the alternate form of mRNA processing appears to be cell type specific. We have not detected a form of $\mathrm{pp} 60^{\mathrm{c}-s r c}$ similar to that found in neurons in any other cell type after extensive examination of a variety of tissues and cultured cells. This alternate form of the amino-terminal region of pp60 ${ }^{c-s s c}$ could allow the c-src gene product to interact with neuron-specific receptor proteins, thus conferring responsiveness to different signals in distinct cell types. Alternatively, this amino-terminal region could influence the substrate specificity of $\mathrm{pp} 60^{\mathrm{c}-\mathrm{src}}$.

Recently, Martinez, Mathey-Prevot, Bernards, and Baltimore have isolated and characterized a c-src-related cDNA clone derived from mouse brain mRNA molecules. The nucleotide sequence of this cDNA is closely related to the coding sequences of the chicken and human c-src genes except that it contains an additional 18 nucleotides located at the junction between the sequences that encode exons 3 and 4 of the genomic copy of chicken c-src gene. The predicted amino acid sequence of the protein encoded by this cDNA contains few amino acid differences compared to the human and chicken pp $60^{\mathrm{c}-\mathrm{src}}$ proteins, with the exception of the additional six amino acids between amino acids 117 and 118. It is likely that this insertion is responsible for the altered mobility of the neuronal c-src gene product, since the pp60 $0^{\mathrm{c}-s \mathrm{~s} c}$ protein expressed in cells carrying this cDNA displays an altered mobility on SDS-polyacrylamide gels compared to the mobility of mouse fibroblastic pp60 ${ }^{\text {c-src }}$ (R. Martinez, B. Mathey-Prevot, A. Bernards, and D. Baltimore, pers. comm.). The position of this insertion would be predicted from the peptide analysis performed in our laboratory. Digestion with Staphylococcus V8 protease indicated that the position of the structural alteration in the $\mathrm{pp} 60^{\mathrm{c}-s \mathrm{rcl}+1}$ is within the amino-terminal 16,000 daltons of the protein (Brugge et al. 1985). We have shown by further peptide analysis (using chemical cleavage at tryptophan residues) that the alteration is upstream from amino acid residue 118 . By analysis of a 52,000 cleavage product which lacks the amino-terminal 8000 daltons of $\mathrm{pp} 60^{\mathrm{c}-\mathrm{src}+\mathrm{l}}$, we predicted that the alteration is downstream from amino acid residue 60 (A. Lustig and J. Brugge, unpubl.).

We have previously reported that the specific activity of pp60-ssc from neuronal cultures is 6- to 12 -fold greater than that of astrocytes and fibroblasts. Cartwright and co-workers have also found that $\mathrm{pp} 60^{\mathrm{c}-s \mathrm{sc}}$ expressed in cultured neurons from rat embryonic striatum also possesses an elevated kinase activity (Cartwright et al., in press|. The pp $60^{\text {c-src }}$ protein from one neuroblastoma cell line was also reported to display an activated kinase activity (Bolen et al. 1985). Elevated levels of activity have also been shown to correlate with alterations with the amino-terminal region of pp60 $60^{\mathrm{c}-s r c}$ and pp60 $60^{\mathrm{v}-s \mathrm{rc}}$ in fibroblasts (Purchio et al. 1983; Collett et al. 1984; Ralston and Bishop 1985; Yonemoto et al. 1985). The experiments reported here indicate at least two structural differences between neuronal and astrocytic pp $60^{c-s r c}$ molecules that could contribute to this increase in activity: (1) an additional site(s) of serine phosphorylation within the amino-terminal 16,000 daltons of the molecule, and (2) a structural alteration (possibly resulting from altered processing of c-src mRNA) that results in an altered mobility of pp $60^{\mathrm{c}-s r c}$. Presently, we cannot distinguish how either of these alterations affects the activity of neuronal pp60c-src. Phosphatases that specifically dephosphorylate the neuronal-specific serine phosphorylation site would be useful in addressing this question.

The evidence that $\mathrm{pp} 60^{\mathrm{c}-\mathrm{src}}$ is expressed at high levels in neurons and that this form of $\mathrm{pp} 60^{\mathrm{c}-\mathrm{src}}$ is subject to cell-type-specific alterations in structure strongly supports the possibility that $\mathrm{pp} 60^{\mathrm{c}-\mathrm{src}}$ may play a specific role in neuronal function. Whether this function is involved in promoting differentiation of these specialized cells or in regulating an event that takes place in mature neurons remains to be determined.

\section{Materials and methods}

\section{Cells and tissues}

Pure cultures of neurons and astrocytes were prepared as described previously (Kaufman and Barrett 1983; Brugge et al. 1985) from the metencephalon and telencephalon of 14-day rat embryos and the brain stem of newborn rats, respectively. NIH-(pMcsrc/cos)A cells, obtained from David Shalloway (Pennsylvania State University) were derived from NIH-3T3 cells transfected with a plasmid carrying the chicken c-src gene (Johnson et al. 1985). Tissues were excised from gs $^{-}$embryos and rinsed in phosphate-buffered saline (PBS) before radiolabeling or lysis. The neural retina was carefully teased from the pigmented layer of the retina in the excised eye and any remaining pigmented portions were removed. For samples of limb, the hind limbs were excised and the skin removed. Muscle and connective tissue were then teased from the bones. Therefore, limb refers to a mix of muscle and connective tissues. The brain was excised and the vascular meningeal layers removed from all samples termed "brain." For 3- and 4-day-old embryos, the entire limb bud or brain was utilized. Unlabeled tissues were dounced 10 times in a loose-fitting homogenizer in the lysis buffer. Tissues that were to be labeled 
were placed in medium and were pipetted 10-15 times with a Pasteur pipette to obtain single-cell, or small-clump suspensions. Tissues were removed from rat embryos as described for chicken embryos.

\section{Antisera}

Monoclonal antibody 327 (Lipsich et al. 1983) was obtained from hybridoma cells derived from a mouse immunized with a GAL-v-src fusion gene expressed in Escherichia coli (Gilmer and Erikson 1981|. One microliter of $1: 100$ dilution of ascites fluid was employed in immunoprecipitations. The tumorbearing rabbit (TBR) serum was obtained from animals bearing RSV-induced tumors (Brugge and Erikson 1977).

\section{Radiolabeling}

Tissue samples were radiolabeled with a $2 \mathrm{mCi} / \mathrm{ml}\left[{ }^{32} \mathrm{P}\right]$ orthophosphate (carrier free, ICN, Irvine, California) for $4 \mathrm{hr}$ in DME minus phosphate. Cells were labeled with $1 \mathrm{mCi} / \mathrm{ml}{ }^{32} \mathrm{P}$ in DME minus phosphate (GIBCO, Grand Island, New York) for 4to 6-hr labeling periods. For 16- to 24-hr labeling periods, the phosphate-free medium was supplemented with $5 \%$ complete DME and $5 \%$ horse serum (astrocytes) or $5 \%$ N2 neuronal culture medium and $5 \%$ serum factor $55 \mathrm{~K}$ (Kaufman and Barrett 1983) (neurons]. Cells were labeled with $0.25 \mathrm{mCi} / \mathrm{ml}\left[{ }^{3} \mathrm{H}\right] \mathrm{my}-$ ristic acid (NEN, Boston, Massachusetts for $4 \mathrm{hr}$ in complete DME (fibroblasts, astrocytes) or in N2 neuronal medium (neurons). The myristic acid was dried under nitrogen and resuspended in DMSO before dilution $(1: 100)$ into medium. Cells were labeled with $0.1 \mathrm{mCi} / \mathrm{ml}\left[{ }^{35} \mathrm{~S}\right]$ methionine $(1000 \mu \mathrm{Ci} / \mathrm{mM}$, Amersham, Arlington Heights, Illinois) for $4 \mathrm{hr}$ in DME minus methionine (GIBCO).

\section{RNA isolation and in vitro translations}

RNA was extracted from cytoplasmic extracts of tissues as described (Maniatis et al. 1982). Polyadenylated RNA was fractionated on oligo (dT)-cellulose columns (Pharmacia). Translation reactions were performed using lysates purchased from Promega Biotec (Madison, Wisconsin) under the conditions recommended by the supplier.

\section{Immunoprecipitation assays}

Tissues were lysed in SLB buffer [ $1 \%$ sodium deoxycholate, $1 \%$ Nonidet P-40, $0.75 \mathrm{M} \mathrm{NaCl}, 5 \mathrm{~mm}$ EDTA, $1 \mathrm{~mm}$ ethylene glycol-bis-( $\beta$-aminoethyl ether)- $N, N$-tetracetic acid (EGTA), 10 mM Tris- $\mathrm{HCl}(\mathrm{pH} 7.0)]$, and cultured cells were lysed in RIPA buffer (same as SLB above plus $0.1 \%$ SDS). The cell lysates were clarified, incubated with antibodies, and the immune complexes washed as described previously using formalin-fixed Staphylococcus aureus as immunoadsorbent (Lipsich et al. 1983). The samples were electrophoresed on $7.5 \%$ SDS-polyacrylamide gels, 9 inches in length.

\section{Peptide mapping}

For partial proteolytic peptide mapping, the proteins were excised from unfixed gels and subjected to partial proteolysis using the method of Cleveland et al. (1977). Samples were subject to electrophoresis in the presence of $S$. aureus V8 protease (ICN Immunobiologicals, Lisle, Illinois) on $12.5 \%$ SDS-polyacrylamide gels. Complete proteolysis with trypsin was performed on proteins isolated from gel pieces as described (Beemon and Hunter 1978). Three successive treatments with 5 $\mu \mathrm{g}$ of TPCK-trypsin (Worthington Biochemical, Freehold, New Jersey/ were performed. For two-dimensional separation of peptides, the first-dimension separation was performed at $\mathrm{pH} 8.9$ on a Savant electrophoresis apparatus, and the second dimension was chromatographed in $n$-butanal/pyridine/acetic acid/ $\mathrm{H}_{2} \mathrm{O}, 300: 200: 60: 240$. For one-dimensional separations, the samples were electrophoresed on $27 \%$ Tris-borate gels (Maurer and Allen 1972).

\section{Phosphatase treatment}

Following washes with RIPA buffer, the immunoprecipitates were washed with phosphatase assay (PA) buffer $140 \mathrm{mM}$ PIPES, $\mathrm{pH}$ 6.0, $1 \mathrm{~mm}$ dithiothreitol, $20 \mu \mathrm{g} / \mathrm{ml}$ aprotinin, $20 \mu \mathrm{M}$ leupeptin) and treated with $6 \mu \mathrm{g}$ of potato acid phosphatase for 10 min at $30^{\circ} \mathrm{C}$ as described (Cooper and King 1986).

\section{Autoradiography}

${ }^{32} \mathrm{P}-\mathrm{Labeled}$ samples were exposed to XAR film (Kodak, Rochester, New York) in the presence of Lightning-Plus intensifying screens. Gels containing ${ }^{35} \mathrm{~S}$ or ${ }^{3} \mathrm{H}$ were fluorographed using Enhance (NEN) for $45 \mathrm{~min}$ and exposed to XAR film.

\section{Acknowledgments}

We would like to thank Tony Hunter, Walter Eckhart, and Gernot Walter for communicating unpublished results and Andy Golden and Joan Levy for critical comments on the manuscript. We also acknowledge Kathy Donnelly for secretarial assistance. This work was supported by grants CA27951 and CA28146 (J.S.B.), NS21728 (R.W.K.), and NS12207 (J.N.B.) from the National Institutes of Health.

\section{References}

Anderson, S., C.P. Gibbs, A. Tanaka, H.-J. Kung, and D. Fugita. 1985. Human cellular src gene: Nucleotide sequence and derived amino acid sequence of the region coding for the carboxy-terminal two-thirds of pp60 ${ }^{\text {c-ssc }}$. Mol. Cell. Biol. 5: $1122-1129$.

Barnekow, A. and M. Shartl. 1984. Cellular src gene product detected in the freshwater sponge Spongilla lacustris. Mol. Cell. Biol. 4: 1179-1181.

Beemon, K. and T. Hunter. 1978. Characterization of Rous sarcoma virus src gene products synthesized in vitro. J. Virol. 28: $551-566$.

Ben-Neriah, Y., A. Bernarris, M. Paskind, G. Daley, and D. Baltimore. 1986. Alternative $5^{\prime}$ exons in c-abl mRNA. Cell 44: $577-586$.

Bishop, J.M. and H.E. Varmus. 1985. Functions and origins of retroviral transforming genes. In RNA Tumor Viruses (ed. R. Weiss, N. Teich, H. Varmus, and J. Coffin), p. 249-356. Cold Spring Harbor Laboratory, Cold Spring Harbor, New York.

Bolen, J.B., N. Rosen, and M.A. Israel. 1985. Increased pp60 ${ }^{\mathrm{c}-s r c}$ tyrosyl kinase activity in human neuroblastomas is associated with aminoterminal tyrosine phosphorylation of the src gene product. Proc. Natl. Acad. Sci. 82: 7275-7279.

Brugge, J.S. and R.L. Erikson. 1977. Identification of a transformation-specific antigen induced by an avian sarcoma virus. Nature 269: 346-348.

Brugge, J.S., P.C. Cotton, A.E. Queral, J.N. Barrett, D. Nonner, and R.W. Keane. 1985. Neurons express high levels of a structurally modified activated form of pp60 ${ }^{\mathrm{c}-s r c}$. Nature 316: $554-557$.

Buss, J.E., M.R. Kamps, and B.M. Sefton. 1984. Myristic acid is attached to the transforming protein of Rous sarcoma virus during or immediately after synthesis and is present in both soluble and membrane bound forms of the protein. Mol. Cell. Biol. 4: 2697-2704.

Cartwright, C.A., R. Simantov, P.L. Kaplan, T. Hunter, and W. 
Eckhart. 1987. Alterations in pp60c-src accompany differentiation of neurons from rat embryo striatum. Mol. Cell. Biol. (in press).

Cleveland, D.W., S.G. Fisher, M.W. Kirschner, and U.K. Laemmli. 1977. Peptide mapping by limited proteolysis in sodium dodecylsulfate and analysis by gel electrophoresis. $I$. Biol. Chem. 252: 1102-1106.

Collett, M.S., E. Erikson, and R.L. Erikson. 1979a. Structural analysis of the avian sarcoma virus-transforming protein: Sites of phosphorylation. J. Virol. 29: 770-781.

Collett, M.S., S.K. Belzer, and A.F. Purchio. 1984. Structurally and functionally modified forms of pp60 ${ }^{\mathrm{c}-s r c}$ in Rous sarcoma virus-transformed cell lysates. Mol. Cell. Biol. 4: 12131220.

Collett, M.S., E. Erikson, A.F. Purchio, J.S. Brugge, and R.L. Erikson. 1979b. A normal cell protein similar in structure and function to the avian sarcoma virus transforming gene product. Proc. Natl. Acad. Sci. 76: 3159-3163.

Cooper, J. and C. King. 1986. Dephosphorylation or antibody binding to the carboxy terminus stimulates pp60 ${ }^{\mathrm{c}-s r c}$. Mol. Cell. Biol. 6: 4467-4477.

Cooper, J.A., K.L. Gould, C.A. Cartwright, and T. Hunter. 1986. $\mathrm{Tyr}^{527}$ is phosphorylated in pp60 ${ }^{\mathrm{c}-s r c}$ : Implications for regulation. Science 231: 1431-1434.

Cotton, P.C. and J.S. Brugge. 1983. Neural tissues express high levels of the cellular src gene product, pp60 c-src. Mol. Cell. Biol. 3: $1157-1162$.

Coussens, P.M., T. Cooper, T. Hunter, and D. Shalloway. 1985. Restriction of the in vitro and in vivo tyrosine kinase activities of pp60 ${ }^{\text {c-src }}$ relative to pp60 ${ }^{\mathrm{v}-s r c}$. Mol. Cell. Biol. 5: 27532763.

Gilmer, T. and R.L. Erikson. 1981. Rous sarcoma virus transforming protein, pp $60^{\mathrm{c}-s r c}$, expressed in $E$. coli, functions as a protein kinase. Nature 294: 771-773.

Hoffman, F.M., L.D. Fresco, H. Hoffman-Falk, and B.-Z. Shilo 1983. Nucleotide sequences of the Drosophila src and $a b l$ homologs: Conservation and variability in the src family oncogenes. Cell 35: 393-401.

Iba, H., F.R. Cross, E.A. Garber, and H. Hanafusa. 1985. Low level of cellular protein phosphorylation by non-transforming overproduced pp60 ${ }^{\text {c-src }}$. Mol. Cell. Biol. 5: $1058-$ 1066.

Iba, H., T. Takeya, F. Croff, T. Hanafusa, and H. Hanafusa. 1984. Rous sarcoma virus variants which carry the cellular src gene cannot transform chicken embryo fibroblasts. Proc. Natl. Acad. Sci. 81: 4424-4428.

Johnson, P., P. Coussens, A. Danko, and D. Shalloway. 1985. Overexpressed pp60 $0^{\mathrm{c}-s r c}$ can induce focus formation without complete transformation of NIH 3T3 cells. Mol. Cell. Biol. 5: 1073-1083.

Kaufman, L.F. and J.N. Barrett. 1983. Serum factor supporting long-term survival of rat central neurons in culture. Science 220: 1394-1396.

Levy, B.T., L.K. Sorge, A. Meymandi, and P.F. Maness. 1984. pp60-src kinase is in chick and human embryonic tissues. Dev. Biol. 104: 9-17.

Levy, J., H. Iba, and H. Hanafusa. 1986. Activation of the transforming potential of pp60 6 -src by a single amino acid change. Proc. Natl. Acad. Sci. 83: 4228-4232.

Lipsich, L.A., A.J. Lewis, and J.S. Brugge. 1983. Isolation of monoclonal antibodies that recognize the transforming proteins of avian sarcoma viruses. J. Virol. 48: 352-360.

Maniatis, T., E.F. Fritsch, and J. Sambrook. 1982. Molecular cloning: A laboratory manual. Cold Spring Harbor Laboratory, Cold Spring Harbor, New York.

Maurer, H.R. and R.C. Allen. 1972. Useful buffer and gel systems for polyacrylamide gel electrophoresis. Z. Klin. Chem. Klin. Biochem. 10: 220.

Oppermann, H., A.D. Levinson, H.E. Varmus, L. Levintow, and J.M. Bishop. 1979. Uninfected vertebrate cells contain a protein that is closely related to the product of the avian sarcoma transforming gene $(\mathrm{src})$. Proc. Natl. Acad. Sci. 76: $1804-1808$.

Parker, R., H. Varmus, and J.M. Bishop. 1984. Expression of $\mathrm{v}$-src and chicken c-src in rat cells demonstrates qualitative differences between $\mathrm{pp} 60^{\mathrm{v}-s r c}$ and $\mathrm{pp} 60^{\mathrm{c}-\mathrm{src}}$. Cell 37:131139.

Parker, R., G. Mardon, R. Lebo, H. Varmus, and J.M. Bishop. 1985. Isolation of duplicated human c-src genes located on chromosomes 1 and 20. Mol. Cell. Biol. 5: 831-838.

Purchio, A.F., S.K. Wells, and M.S. Collett. 1983. Increase in the phosphotransferase activity of purified Rous sarcoma virus, pp60v-src protein, after incubation with ATP/ $\mathrm{Mg}^{2+}$. Mol. Cell. Biol. 3: 1589-1597.

Ralston, R. and J.M. Bishop. 1985. The product of the proto-oncogene c-src is modified during the cellular response to platelet-derived-growth factor. Proc. Natl. Acad. Sci. 82: 7845-7849.

Rohrschneider, L.R., R.N. Eisenman, and C.R. Leitch. 1979. Identification of a Rous sarcoma virus transformation-related protein in normal avian and mammalian cells. Proc. Natl. Acad. Sci. 76: 4479-4483.

Schartl, M. and A. Barnekow. 1984. Differential expression of the cellular src gene during vertebrate development. Dev. Biol. 105: 415-422.

Schultz, A.M., L.E. Henderson, S. Oroszlan, E.A. Garber, and H. Hanafusa. 1985. Aminoterminal myristylation of protein kinase $\mathrm{pp} 60^{\mathrm{src}}$, a retroviral transforming protein. Science 227: 427-429.

Semba, K., M. Nishizawa, N. Miyajima, M.C. Yoshide, J. Sukegawa, Y. Yamanashi, M. Sasaki, T. Yamamoto, and K. Toyoshima. 1986, yes-related protooncogene, syn, belongs to the protein-tyrosine kinase family. Proc. Natl. Acad. Sci. 83: $5459-5463$.

Shalloway, D., P.M. Coussens, and P. Yaciuk. 1984. Overexpression of the c-src protein does not induce transformation of NIH-3T3 cells. Proc. Natl. Acad. Sci. 81: 7071-7075.

Simon, M., B. Dress, T. Kornberg, and J.M. Bishop. 1985. The nucleotide sequence and the tissue-specific expression of Drosophila c-src. Cell 42: 831-840.

Sorge, L.K., B.T. Levy, and P.F. Maness. 1984. pp60c-src is developmentally regulated in the neural retina. Cell 36: 249-257.

Stehelin, D., H.E. Varmus, J.M. Bishop, and P.K. Vogt. 1976. DNA related to the transforming gene(s) of avian sarcoma virus is present in normal avian DNA. Nature 260: 170173.

Sudol, M. and H. Hanafusa. 1986. Cellular proteins homologous to the viral yes gene product. Mol. Cell. Biol. 6: 2839-2846.

Sukegawa, J., K. Semba, Y. Yamanashi, M. Nishizawa, N. Miyajima, T. Yamamoto, and K. Toyoshima. 1987. Characterization of cDNA clones for the human c-yes gene. Mol. Cell. Biol. 7: 41-47.

Takeya, T. and H. Hanafusa. 1983. Nucleotide sequence of c-src. Cell 32: 881-890.

Yonemoto, W., M. Jarvis-Morar, J.S. Brugge, J. Bolen, and M. Israel. 1985. Novel tyrosine phosphorylation within the amino-terminal domain of pp60 ${ }^{\mathrm{c}-s r c}$ molecules associated with polyoma virus middle-sized tumor antigen. Proc. Natl. Acad. Sci. 82: 4568-4572. 


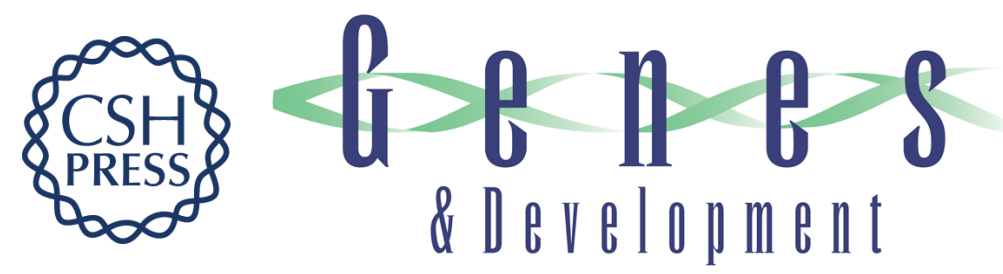

\section{Characterization of the altered form of the c-src gene product in neuronal cells.}

J Brugge, P Cotton, A Lustig, et al.

Genes Dev. 1987, 1:

Access the most recent version at doi:10.1101/gad.1.3.287

References This article cites 43 articles, 29 of which can be accessed free at: http://genesdev.cshlp.org/content/1/3/287.full.html\#ref-list-1

\section{License}

Email Alerting

Receive free email alerts when new articles cite this article - sign up in the box at the top Service right corner of the article or click here.

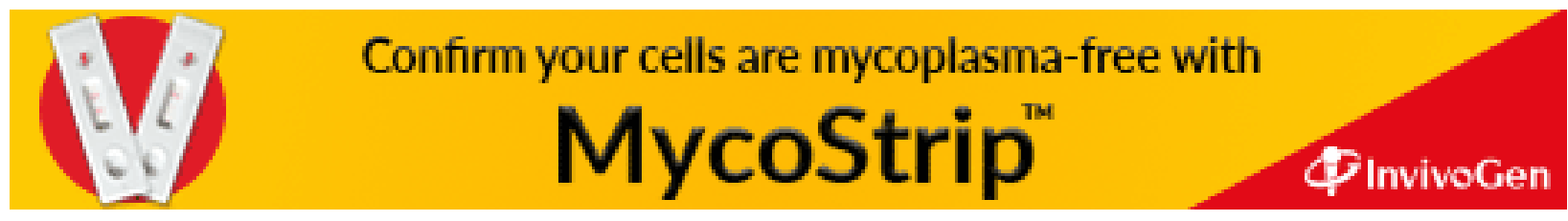

